УДК 339.9:620.9](438)".../2040"

\title{
ЕНЕРГЕТИЧНА ПОЛІТИКА ПОЛЬЩ ДО 2040 Р.: ОСНОВИ, ЦІЛІ ТА КЛЮЧОВІ ЕЛЕМЕНТИ
}

\section{ENERGY POLICY OF POLAND UNTIL 2040: FUNDAMENTALS, GOALS AND KEY ELEMENTS}

\author{
Паламарчук Дмитро Миколайович \\ кандидат економічних наук, доцент, \\ Черкаський державний технологічний університет \\ ORCID: https://orcid.org/0000-0002-6023-9780 \\ Паламарчук Наталія Олександрівна \\ кандидат економічних наук, доцент, \\ Черкаський державний технологічний університет \\ ORCID: https://orcid.org/0000-0003-1076-0401 \\ Palamarchuk Dmytro, Palamarchuk Nataliia \\ Cherkasy State Technological University
}

\begin{abstract}
В статті досліджено особливості трансорормації енергетичної політики Польщі, що ґрунтується на проведенні суцільної трансорормації в енергетичній сорері, залученні всіх зацікавлених сторін у процеси розвитку енергетичної політики, модернізації та інноваційному оновленні енергетичної ссрери, стимулювання економічного розвитку, ефективності та конкурентоспроможності як основи для економічного зростання. Особлива увага відведена аналізу енергетичної політики Польщі до 2040 р. Зокрема, в статті проаналізовано основи енергетичної політики: справедлива трансорормація, система нульових викидів енергії, висока якість повітря. Також розглянуто цілі та стратегічні проекти, ключові елементи та основні цільові показники енергетичної політики Польщі. Окрема увага приділена регіональним особливостям енергетичної політики, а також механізму її фрінансування.
\end{abstract}

Ключові слова: енергетична політика, енергозбереження, енергоефективність, альтернативна енергетика, атомна енергетика, справедлива трансорормація.

В статье исследованы особенности трансформации энергетической политики Польши. В её основе - проведении общей трансорормации в энергетической сфере, привлечении всех заинтересованных сторон в процессы развития энергетической политики, модернизации и инновационном обновлении энергетической ссреры, стимулирование экономического развития, эфрфективности и конкурентоспособности как основы для экономического роста. Особое внимание отведено анализу энергетической политики Польши до 2040 г. В частности, в статье проанализированы основы энергетической политики: справедливая трансорормация, система нулевых выбросов энергии, высокое качество воздуха. Также рассмотрены цели и стратегические проекты, ключевые элементы и основные целевые показатели энергетической политики Польши. Особое внимание уделено региональным особенностям энергетической политики, а также механизму её фринансирования.

Ключевые слова: энергетическая политика, энергосбережение, энергоэффективность, альтернативная энергетика, атомная энергетика, справедливая трансформация.

Global threats, national problems, and integration conditions of development have led to the transformation of the energy policy of Poland. In today's world development, the country needs to prevent global climate change, change the structure of energy resources, carry out technical modernization, implement the basics of energy saving and energy efficiency, and comply with the common energy policy of the EU. All these aspects are taken into account by the Energy Policy of Poland until 2040, which contains the basics of energy policy, relevant goals and strategic projects, key elements and key targets for assessing the results of implementation. The purpose of this article is to study and analyze the features of the energy policy of Poland at the present stage of world development. The historical method, analytical method, basics of analysis and generalization were used in the research process. As a result of the study, it can be concluded about the systemic transformation of the energy policy of Poland. It is based on a fair transformation, a zero-emission energy system, as well as ensuring high air quality. A fair transformation involves the transformation of coal regions, the reduction of energy poverty, and the creation of new industries 
related to renewable energy and nuclear energy. The zero-emission energy system includes the development of alternative energy, nuclear energy, as well as the regional energy sector. Ensuring high air quality is based on the transformation of the thermal sector, electrification of transport and passive buildings. In accordance with the basics, special goals of energy policy have been formed: optimal use of own energy resources, development of electricity production and network infrastructure, diversification of supplies and expansion of network infrastructure of natural gas, crude oil, and liquid fuel, development of energy markets, the introduction of nuclear energy, development of renewable energy sources, heating and cogeneration, an increase of energy efficiency. Appropriate strategic projects have been developed for the practical implementation of the goals. For the overall assessment of the degree of policy implementation, the key elements and main targets of energy policy have been emphasized. Thus, the energy policy of Poland at the present stage is a holistic mechanism of energy development in response to global and national development trends. The practical value of this study is that its results can be used to improve the energy policies of different countries, such as Ukraine.

Keywords: energy policy, energy saving, energy efficiency, alternative energy, nuclear energy, fair transformation.

Постановка проблеми. Однією з тенденцій сучасного світового розвитку є трансформація енергетичної політики відповідно до сучасних глобальних викликів. Всі розвинені країни світу вдосконалюють національні енергетичні політики 3 метою забезпечення енергетичних потреб країни. В основі більшості енергетичних політик країн - раціональне використання енергетичних ресурсів, розвиток альтернативної енергетики, підвищення енергоефективності. В той же час основним завданням енергетичної трансформації $€$ забезпечення економічного зростання та соціального добробуту країни. Польща має унікальний досвід вдосконалення енергетичної політики, в основі якого синергія глобальних викликів, спільна енергетична політика $€ C$, а також врахування національних особливостей розвитку.

Аналіз останніх досліджень та публікацій. Дослідженню особливостей енергетичної політики Польщі присвячені праці таких вчених як Антонова Л.В., Демяненко Н.В., Зоря О.П., Ішков С.В., Манжул І.В., Зеленько В.А., Зеленько Н.М., Слюсар О., Френчак Я.І., Шатило О.А. та інших вчених. В їх працях досліджено основи формування енергетичної політики Польщі, законодавчі та інституційні основи енергетичної безпеки країни, значення європейської інтеграції для розвитку енергетичної політики Польщі. Окремої уваги потребує аналіз особливостей енергетичної політики Польщі на сучасному етапі світового розвитку та визначення стратегічних пріоритетів розвитку країни.

Виділення невирішених раніше частин загальної проблеми. Потребує більш ґрунтовного дослідження енергетична політика Польщі на сучасному етапі світового розвитку, особливо її транссрормація до 2040 р.

Постановка завдання. Основним завданням даної статті $€$ дослідження та аналіз особливостей енергетичної політики Польщі на сучасному етапі світового розвитку.
Виклад основного матеріалу дослідження. Основи сучасної енергетичної політики Польщі почали фрормуватися у 90-х рр. XX ст. Вона передбачала виокремлення стратегічних завдань політики, розробку прогнозів на енергетичні ресурси, аналіз проблем енергетичної безпеки та поетапний план реалізації енергетичної політики [1, с. 156]. Міжнародна енергетична агенція підтримує процес трансорормації енергетичної політики країни, а також рекомендує Польщі диверсифікувати джерела та шляхи постачання енергетичних ресурсів, активно впроваджувати заходи 3 енергоефективності, вдосконалювати нормативно-правове забезпечення, а також залучати інвестиції в процеси вдосконалення енергетичної сорери країни [2].

Після вступу Польщі до ЄС ії̈ енергетична політика почала змінюватись відповідно до норм Європейського Союзу. Основними завданнями спільної енергетичної політики $€ \subset €$ : забезпечення енергетичної ефективності, фрормування спільного енергетичного ринку, забезпечення енергетичної безпеки в регіоні, впровадження енергетичних інновацій, розвиток міжнародної співпраці в енергетичній сорері [3, с. 47].

Враховуючі глобальні зміни клімату, основним вектором сучасної енергетичної політики $€ C €$ енергоедективність. 3 врахуванням цього країни ЄС проводять енергоефективні відновлювальні роботи будівель та споруд, встановлюють вимоги щодо енергоефрективності, впроваджують сертифрікати та стандарти енергетичної ефективності, розробляють фрінансові інструменти для реалізації заходів з енергоефрективності, готують національні плани, зобов'язують великі компанії проходити енергоаудит [4, с. 20].

Основним інститутом, що займається розробкою та реалізацією енергетичної стратегії Польщі є Міністерство економіки Польщі. Основна відповідальність за фрормування 
національної енергетичної політики покладається на Департамент енергетики. Він контролює єдність енергетичної політики в країні, готує нормативно-правове забезпечення для енергетичної сфрери, опікується забезпеченням національної системи енергетичної безпеки, стимулює впровадження інноваційних енергетичних технологій. У складі Міністерства $€$ два департаменти, що займаються пріоритетними напрямами енергетичної політики Польщі - Департамент відновних видів енергії та Департамент атомної енергетики. За збір та обробку інформації відповідає Департамент стратегії та аналізу.

Забезпеченням національної енергетичної безпеки займається Рада національної безпеки, під її контролем - актуальні загрози національній безпеці в енергетичній сфері. Для ліцензування діяльності в енергетичній сфрері, фрормування та контроль тарифів за використання енергетичних ресурсів та захисту конкуренції на енергетичному ринку країни створено Управління з регулювання енергетики [5].

Основним нормативно-правовим актом, що регулює енергетичну політику Польщі $€$ Закон Республіки Польща «Про енергетику» від 10.05.1997 р., він визначає основні інститути у сорері енергетики та межі їх відповідальності. Для забезпечення енергетичної ефрективності прийнято Закон Республіки Польща «Про енергетичну ефективність» від 20.05.2016 р., він регулює особливості підготовки національного плану щодо енергетичної ефрективності, механізм досягнення енергоефективності, порядок проведення аудиту енергоесрективності підприємств та штрасрні санкції за порушення у сфері енергоефрективності [6, с. 16].

Транссормація енергетичної політики Польщі в сучасних умовах ґрунтується на: проведенні суцільної трансфрормації в енер- гетичній сфрері, залученні всіх зацікавлених сторін у процеси розвитку енергетичної політики, модернізації та інноваційному оновленні енергетичної ссрери, стимулювання економічного розвитку, ефеективності та конкурентоспроможності як основи для економічного зростання.

Енергетична політика Польщі до 2040 р. ґрунтується на 3 концептуальних основах (табл. 1).

Справедлива транссормація має на меті залучення регіонів та громад до процесів трансорормації енергетичної політики 3 ціллю впровадження низьковуглецевого підходу. Особливо це стосується відсталих регіонів де низьковуглецевий підхід впроваджується 3 відставанням. Також передбачається розвиток нових галузей і створення додаткових робочих місць з метою розвитку енергетичного сектору країни. Для транссоормації вугільних регіонів країни заплановано фрінансування у обсязі 60 млрд. злотих. У процесах транссрормації запланована участь окремих споживачів енергії, для них передбачений захист від підвищення цін, а також система заохочень 3 метою збільшення їх участі в енергетичному ринку. Весь цей підхід має на меті справедливе залучення всіх бажаючих до процесів транссрормації енергетичної політики країни. В процесі впровадження цього підходу планується створити 300 тис. робочих місць у галузях з високим потенціалом, що пов'язані з відновлювальною та атомною енергетикою, термомодернізацією та електромобільністю. Основою для справедливої трансорормації $\epsilon$ використання внутрішніх конкурентних переваг, створення нових можливостей для розвитку, а також проведення модернізації енергетичного сектору країни.

Система нульових викидів енергії - це довгострокова перспектива для розвитку енерге-

Таблиця 1

Основи енергетичної політики Польщі

\begin{tabular}{|c|c|c|}
\hline $\begin{array}{l}\text { Справедлива } \\
\text { трансфрормація }\end{array}$ & $\begin{array}{c}\text { Система нульових викидів } \\
\text { енергії }\end{array}$ & Висока якість повітря \\
\hline $\begin{array}{c}\text { Трансорормація вугільних } \\
\text { регіонів }\end{array}$ & Альтернативна енергетика & $\begin{array}{c}\text { Транссрормація теплового } \\
\text { сектору }\end{array}$ \\
\hline $\begin{array}{c}\text { Зменшення енергетичної } \\
\text { бідності }\end{array}$ & Атомна енергетика & Електрифрікація транспорту \\
\hline $\begin{array}{c}\text { Нові галузі, пов'язані з } \\
\text { відновлюваною енергетикою } \\
\text { та атомною енергетикою }\end{array}$ & $\begin{array}{c}\text { Сектор } \\
\text { регіональної } \\
\text { енергетики }\end{array}$ & $\begin{array}{c}\text { Енергопасивні } \\
\text { будинки }\end{array}$ \\
\hline
\end{tabular}


тики Польщі. Для її реалізації передбачається розвиток атомної та альтернативної енергетики як найбільш перспективного напряму розвитку енергетики в сучасних умовах світового розвитку. Стимулюється також зростання ролі сектору регіональної енергетики. У промисловості передбачено розширений перехід до енергетично безпечних технологій, зокрема з використанням газоподібного палива.

Висока якість повітря - це мета енергетичної трансформації, яка $€$ основною якісною характеристикою всіх проведених реформ. В даному напрямку передбачено збільшення інвестицій у трансорормацію теплового сектору, електрифрікацію транспорту та розвиток енергопасивних будинків. Всі ці зміни дозволять підвищити якість повітря в країні, що стене ключовим результатом енергетичних трансфрормацій які відчує кожен громадянин завдяки покращення власного здоров'я.

Відповідно до основ енергетичної політики сфрормовано спеціальні цілі та відповідні стратегічні проекти (табл. 2).

Сучасна енергетична політика Польщі $€$ відповіддю на актуальні виклики щодо енерге- тичних потреб країни. Вона визначає напрями ресрормування енергетичного сектору з врахуванням короткої, середньої та довгострокової перспектив розвитку. Енергетична політика входить до дев'яти стратегій розвитку, що сорормовані на основі Системи управління розвитком країни, її головна мета - створити умови для зростання доходів жителів Польщі з одночасним збільшенням соціальної, економічної, екологічної та територіальної згуртованості.

Енергетична політика Польщі до 2040 р. має прямий зв'язок з Національною екологічною політикою 2030, Стратегією сталого розвитку транспорту до 2030 року щодо зменшення викидів СО2 та забруднюючих речовин, Стратегією сталого розвитку сільських територій, сільського господарства та рибного господарства 2030 що регламентує використання потенціалу сільського господарства та сільських територій в енергетичних цілях, Стратегією продуктивності та Національною стратегією регіонального розвитку 2030 у сорері гармонійного поєднання розвитку енергетичного сектору, забезпечення про-

Цілі та стратегічні проекти енергетичної політики Польщі

Таблиця 2

\begin{tabular}{|c|c|c|}
\hline $\begin{array}{c}\text { ЦІЛЬ } 1 . \\
\text { Оптимальне використання } \\
\text { власних енергетичних } \\
\text { ресурсів } \\
\text { СТРАТЕГІЧНИЙ ПРОЕКТ } 1 . \\
\text { Транссрормація вуглецевих } \\
\text { регіонів }\end{array}$ & $\begin{array}{c}\text { ЦІЛЬ } 2 . \\
\text { Розвиток виробництва } \\
\text { електроенергії та мережевої } \\
\text { інфрраструктури } \\
\text { СТРАТЕГІЧНИИ ПРОЕКТ 2А. } \\
\text { Ринок елекЈроенергії } \\
\text { СТРАТЕГІЧНИЙ ПРОЕКТ 2В. } \\
\text { Впровадження розумних } \\
\text { електромереж }\end{array}$ & $\begin{array}{c}\text { ЦІЛЬ } 3 . \\
\text { Диверсифікація поставок } \\
\text { та розширення мережевої } \\
\text { інфраструктури природного } \\
\text { газу, сирої нафтт та рідкого } \\
\text { палива } \\
\text { СТРАТЕГІЧНИЙ ПРОЕКТ ЗА. } \\
\text { Будівництво Балтійської } \\
\text { труби } \\
\text { СТРАТЕГІЧНИЙ ПРОЕКТ ЗВ. } \\
\text { Будівництво другої лінії } \\
\text { Поморського трубопроводу }\end{array}$ \\
\hline $\begin{array}{c}\text { ЦІЛЬ } 4 . \\
\text { Розвиток енергетичних ринків } \\
\text { СТРАТЕГІЧНИЙ ПРОЕКТ 4А. } \\
\text { Виконання Плану дій (для } \\
\text { збільшення транскордонної } \\
\text { потужності передачі } \\
\text { електроенергії) } \\
\text { СТРАТЕГІЧНИЙ ПРОЕКТ 4В. } \\
\text { Газовий концентратор, } \\
\text { СТРАТЕГІЧНИЙ ПРОЕКТ 4С. } \\
\text { Розвиток електромобільності }\end{array}$ & $\begin{array}{c}\text { ЦІЛІ ТА } \\
\text { СТРАТЕГІЧНІ } \\
\text { ПРОЕКТИ } \\
\text { ЕНЕРГЕТИЧНОЇ ПОЛІТИКИ } \\
\text { ПОЛЬЩІ ДО } 2040 \text { р. }\end{array}$ & $\begin{array}{c}\text { СПЕЦІАЛЬНА ЦІЛЬ } 5 . \\
\text { Впровадження ядерної } \\
\text { енергеЈики } \\
\text { СТРАТЕГІЧНИЙ ПРОЕКТ } 5 . \\
\text { Польська програма ядерної } \\
\text { енергетики }\end{array}$ \\
\hline $\begin{array}{c}\text { ЦІЛь } 6 . \\
\text { Розвиток відновлюваних } \\
\text { джерел енергії } \\
\text { СТРАТЕГІЧНИЙ ПРОЕКТ } 6 . \\
\text { Впровадження офршорної } \\
\text { енергії вітру }\end{array}$ & $\begin{array}{c}\text { ЦІЛЬ } 7 . \\
\text { Розвиток опалення та } \\
\text { когенерації } \\
\text { СТРАТЕГІЧНИИ ПРОЕКТ } 7 . \\
\text { Розробка системи опалення }\end{array}$ & $\begin{array}{c}\text { ЦІЛЬ 8. } \\
\text { Підвищення } \\
\text { енергоедективності } \\
\text { СТРАТЕГІЧНИЙ ПРОЕКТ } 8 . \\
\text { Сприяння вдосконаленню } \\
\text { енергоефрективності }\end{array}$ \\
\hline
\end{tabular}

Джерело: [7, с. 5] 
дуктивності економіки та загального розвитку країни.

Крім цього Енергетична політика Польщі до 2040 р. враховує Стратегію розвитку людського капіталу, Стратегію розвитку соціального капіталу та Ефективну та сучасну державну стратегію. На основі розвитку людського потенціалу має бути створений потенціал знань та навиків, що $є$ базою для трансорормації енергетичного сектору. Соціальний капітал фрормує суспільні відносини та соціальну відповідальність - це створює умови для реалізації енергетичної політики. Енергетична політика також враховує державну політику щодо сировинної бази шляхом постійного її розширення, що є важливою умовою забезпечення енергетичної безпеки.

Ключовими елементами енергетичної політики Польщі до 2040 р. є:

- в енергетичній системі країни має бути сорормована система самозабезпечення електроенергією;

- зростання потужності альтернативної енергетики (вітрової) - у 2030 р. має складати 5,9 ГВт., a у 2040 р. - 11 ГВт.;

- $\quad$ зростання потужності альтернативної енергетики (сонячної) - у 2030 р. має складати 5-7 ГВт., а у 2040 р. - 10-16 ГВт.;

- збільшення частки відновлюваних джерел енергії: у всіх секторах та технологіях - у 2030 році частка відновлюваної енергії у валовому кінцевому споживанні енергії становитиме щонайменше 23\%: не менше $32 \%$ в енергетиці (переважно вітрова та сонячна), $28 \%$ у опаленні (збільшення на 1,1 процентного пункту в рік), 14\% у транспорті (за рахунок електромобільності);

- у 2030 р. частка вугілля у виробництві електроенергії має не перевищувати 56\%;

- скорочення використання вугілля в економіці має відбуватись на основі справедливої транссормації;

- зростання енергоефрективності - у 2030 році на 23\% має зменшитись споживання первинної енергії;

- інвестиційні програми мають бути спрямовані на розвиток відновлюваних джерел енергії та місцевому балансуванні;

- у у 2033 році планується введення в експлуатацію першого блоку атомної електростанції 3 потужністю 1-1,6 ГВт, блоки будуть добудовуватись кожні 2-3 роки, в цілому ядерна програма передбачає будівництво 6 блоків;

- до 2040 р. планується перевести теплопостачання домогосподарств на цен- тралізовану або індивідуальні системи 3 нульовим або низьким рівнем забруднення;

- природній газ має стати паливом у процесі трансформації енергетичної політики,

- у у 2030 році газові мережі мають бути підготовлені до транспортування суміші, що містить приблизно 10\% вуглекислих газів;

- планується розширення інфрраструктури природного газу, сирої насрти та рідкого палива, забезпечена диверсиорікація напрямків постачання;

- планується зниження явища енергетичної бідності до рівня 6\%;

- до 2030 р. викиди парникових газів скоротяться приблизно на 30\% порівняно 3 1990 р.;

- розвиток енергетичних технологій буде спрямований на: технології накопичення енергії, розумні системи обліку та управління енергією, електромобільність та альтернативні види палива, водневі технології;

- система заходів, що буде спрямована на поліпшення якості повітря, включатиме: розвиток централізованого теплопостачання (4-кратне збільшення кількості ефективних систем опалення до 2030 року), низькоемісійний напрямок транссормації окремих джерел (теплові насоси, електричне опалення), відхід від спалення вугілля в домашніх господарствах - у містах до 2030 р., у сільській місцевості до 2040 р.; підвищення енергоефективності будівель; розвиток транспорту 3 низьким рівнем викидів, включаючи громадський транспорт з нульовими викидами до 2030 р. [7, с. 7].

Відповідно до ключових елементів енергетичної політики Польщі можна виокреми основні цільові показники польської енергетичної політики (табл. 3).

Енергетична політика тісно взаємопов'язана з промисловою, інвестиційною та регіональною політиками, має значний вплив на політику зайнятості. Такий взаємозв'язок має на меті забезпечити розвиток паливно-енергетичного сектору на основі довгострокових внутрішніх трансорормацій соціально-економічного розвитку країни.

Регіональний вимір енергетичної політики має на меті забезпечити синергію національного та територіального розвитку за допомогою цілеспрямованого економічного розвитку, планування та програмування енергетичних змін. В основі енергетичної політики на регіональному рівні - зміна системи планування потреби енергії та палива регіону. Нова система планування дозволяє визначити потребу 
Основні цільові показники польської енергетичної політики 2040

\begin{tabular}{|c|c|c|}
\hline Назва показника & $\begin{array}{l}\text { Базове } \\
\text { значення } \\
(2018)\end{array}$ & $\begin{array}{l}\text { Цільове } \\
\text { значення } \\
(2030)\end{array}$ \\
\hline Частка вугілля у виробництві електроенергії, \% & 77 & $\leq 56$ \\
\hline $\begin{array}{l}\text { Частка відновлюваних джерел енергії у валовому кінцевому } \\
\text { споживанні енергії, \% }\end{array}$ & 11,3 & 23 \\
\hline Частка відновлюваних джерел енергії на транспорті, \% & 5,6 & 14 \\
\hline $\begin{array}{l}\text { Середньорічне зростання ВДЕ в опаленні та охолодженні } \\
\text { (порівняно з } 2020 \text { роком), \% }\end{array}$ & 14,5 & $+1,1$ в.п. щороку \\
\hline Споживання первинної енергії, Мтне & 101,1 & $\leq 91,3$ \\
\hline Викиди СО2 (на 30\% менше ніж в 1990 р.), млн. т & 300,5 & $\leq 241$ \\
\hline $\begin{array}{l}\text { Територіальні громади, що займаються енергетичним } \\
\text { плануванням, \% }\end{array}$ & 23 & 100 \\
\hline $\begin{array}{l}\text { Кількість безкоштовних точок зарядки для електричних } \\
\text { транспортних засобів, шт. }\end{array}$ & 900 & 49 тис. \\
\hline $\begin{array}{l}\text { Кількість точок швидкого заряджання для електричних } \\
\text { транспортних засобів, шт. }\end{array}$ & 300 & 11 тис. \\
\hline $\begin{array}{l}\text { Частка автомобілів з нульовими викидами в закупівлях нового } \\
\text { парку громадського транспорту в містах з більш ніж } \\
100 \text { тис. мешканців, \% }\end{array}$ & 4 & 100 \\
\hline \multicolumn{3}{|l|}{ (ціль на 2025 р.) } \\
\hline $\begin{array}{l}\text { Частка транспортних засобів з нульовим рівнем викидів у } \\
\text { парку громадського транспорту в містах з більш ніж } \\
100 \text { тис. мешканців, \% }\end{array}$ & 2 & 100 \\
\hline $\begin{array}{l}\text { Міські домогосподарства, що використовують кам'яне вугілля } \\
\text { для індивідуального опалення приміщень, \% }\end{array}$ & 24,7 & $0 \%$ \\
\hline $\begin{array}{l}\text { Сільські домогосподарства, що використовують кам'яне } \\
\text { вугілля для індивідуального опалення приміщень, \% }\end{array}$ & 88,4 & 0 \\
\hline \multicolumn{3}{|l|}{ (ціль на 2040 р.) } \\
\hline $\begin{array}{l}\text { Кількість міських домогосподарств приєднаних до мереж } \\
\text { центрального опалення }\end{array}$ & 5,3 млн. & $+1,5 \mathrm{млн.}$ \\
\hline Кількість кінцевих споживачів природного газу & 7,2 млн. & $\begin{array}{c}+1,5 \text { млн. } \\
\text { (ціль на } 2024 \text { р.) }\end{array}$ \\
\hline Кількість споживачів відновлюваної енергії & 190 тис. & $1 \mathrm{млн.}$ \\
\hline Рівень енергетичної бідності, \% & 9,4 & 6 \\
\hline
\end{tabular}

Джерело: [7]

та потенціал регіону, а потім використати цю інформацію для побудови або розширення тепломережі, розподілу електроенергії або доступу до природного газу. Всі ці заходи мають на меті зниження викидів та запобігання нових викидів у процесі розвитку житлової інсрраструктури. Ті органи місцевого самоврядування, що будуть підтримувати енергоесрективні ініціативи будуть отримувати додаткове орінансування. Дотримання стандартів у сорері енергетиці стає обов'язком всіх енергетичних компаній, а такою запорукою їх розвитку на ринку.

В процесі реалізації даного підходу особлива увага буде приділена маргінальним регіонам країни. В них буде проведено аналіз стану мереж, розроблені плани по її модернізації, а такою ссрормовані відповідні інвестиційні плани розвитку. В регіонах, де мережа не підлягає модернізації, буде будуватись нова мережа з залученням інвестицій та створенням нових робочих місць. В пріоритеті розвитку нових мереж - відновлювані джерела енергії, атомна енергетика, термічна модернізація, технології газової декарбонізації, електромобільність, автоматизація та енергозбереження.

Згідно комуніке польського міністра по клімату та навколишньому середовищу від 2 березня 2021 року щодо енергетичної політики держави до 2040 року для енергетичної трансорормації Польщі потрібні будуть інвес- 
тиції, обсяг яких за 2021-2040 рр. становитиме близько 1,6 трлн. злотих. Майже 0,9 трлн. злотих буде спрямовано на реалізацію проектів в енергетичному секторі і майже 0,7 трлн. злотих в неенергетичних секторах (в ссрері послуг, промисловості, транспорті, сільському господарстві та житловому секторі).

На 2021-2027 рр. обсяг коштів, що виділяються для Польщі в рамках спільних політик $€ C$ скоротиться, в порівнянні 3 попереднім періодом (у період з 2014 по 2020 рік з європейських фондів Польща отримала близько 86 млрд євро). Це в свою чергу призвело до зміщення фрінансового навантаження на внутрішні (польські) джерела фрінансування (як державні так і приватні).

Тим не менш, за рахунок коштів $€ С$ та внутрішніх ресурсів Польщі до 2030 р. на енергетичну та кліматичну трансфрормацію буде виділено близько 260 млрд. злотих, з них:

- 79 млрд. злотих в межах реалізації Політики згуртованості ЄC (EU cohesion policy; політика націлена на поліпшення економічного добробуту регіонів в Європейському Союзі та уникнення регіональних диспропорцій);

- 97,8 млрд. злотих з Фонду реконструкції та стійкості ЄС (The Recovery and Resilience Facility; даний інструмент створений з метою зменшення впливу пандемії коронавірусу підвищення стійкості європейських економік та кращої підготовленості до зеленого та цифрового переходів);

- 15,6 млрд. злотих з Фонду справедливої трансорормації (The Just Transition Fund; фрінансовий інструмент в рамках політики згуртованості ЄС націлений на підтримку територій, які найбільше постраждали від переходу до кліматичної нейтральності);
- $\quad$ 1,8 млрд. злотих 3 пакету REACT-EU (Пакет REACT-EU включає 55 млрд. євро, які будуть розділені між державами-членами ЄС через європейські фонди. Передбачається що кошти сприятимуть зеленому, циорровому та стійкому відновленню економіки);

- 20 млрд. злотих через інші інструменти;

- 47,6 млрд. злотих залучених через нові інструменти фрінансування енергетичної трансорормації (наприклад, за рахунок коштів отриманих від продажу дозволів на викиди CO2).

Висновки Таким чином можна зробити висновок, що енергетична політика Польщі враховує сучасні тенденції розвитку та відповідає національним інтересам країни. В цілому слід відмітити, що вона зорієнтована на задоволення основних енергетичних потреб країни, враховує ситуацію на ринку праці та структурні зміни національної економіки.

Основними складовими енергетичної політики Польщі на сучасному етапі світового розвитку є: розвиток альтернативної та атомної енергетики, зростання енергоефрективності, розвиток відновлюваних джерел енергії, скорочення використання вугілля, технологічна модернізація енергетичної ссрери, диверсисрікацію джерел та напрямів енергопостачання - все це має дати кінцевий результат у вигляді поліпшення якості повітря та зменшення негативного впливу на навколишнє середовище. На регіональному рівні передбачено енергетичний розвиток з врахуванням потреб регіонів, а також особливі умови для маржинальних регіонів. Фінансування реалізації енергетичної політики Польщі передбачає поєднання національних інвестиційних ресурсів та ресурсів ЄС.

\section{СПИСОК ВИКОРИСТАНИХ ДЖЕРЕЛ:}

1. Манжул І.В. Польський досвід забезпечення енергетичної безпеки. Науковий вісник Міжнародного гуманітарного університету. Сер.: Юриспруденція. 2015. № 15. Том 2. С. 154-157.

2. International Energy Agency. URL: https://www.iea.org.

3. Слюсар О. Стан та перспективи енергетичної безпеки Польщі. Актуальні питання суспільних наук та історії медицини. Спільний українсько-румунський науковий журнал. 2019. № 2 (22). С. 46-50.

4. Зеленько В.А., Френчак Я.І., Зеленько Н.М. Проблема енергоефективності у моделі сталого розвитку України: досвід ЄС. Економіка та управління національним господарством. 2019. № 1 (135). С. 18-23.

5. Шатило О. Світовий досвід забезпечення координації економічної та енергетичної політики: організаційний аспект. Державне управління: удосконалення та розвиток. 2013. № 7. URL: http://www.dy.nayka.com.ua/ ?op $=1 \& z=596$.

6. Енергетична безпека: європейський досвід. Офріс з фрінансового та економічного аналізу у Верховній Раді України. URL: https://feao.org.ua/wp-content/uploads/2016/11/Energy_Security_Final_27.11.pdf.

7. Polityka energetyczna Polski do 2040 r. URL: https://www.gov.pl/web/klimat/polityka-energetyczna-polski. 


\section{REFERENCES:}

1. Manzhul I.V. (2015) Polskyi dosvid zabezpechennia enerhetychnoi bezpeky [Polish experience in energy security]. Naukovyi visnyk Mizhnarodnoho humanitarnoho universytetu. Ser.: Yurysprudentsiia, vol. 15, tom 2, pp. 154-157.

2. International Energy Agency. Available at: https://www.iea.org.

3. Sliusar O. (2019) Stan ta perspektyvy enerhetychnoi bezpeky Polshchi [The state and prospects of Poland`s energy security]. Current issues of social studies and history of medicine. Joint Ukrainian-Romanian scientific journal, no. 2(22), pp. 46-50.

4. Zelenko V.A., Frenchak Ya.I., Zelenko N.M. (2019) Problema enerhoefektyvnosti u modeli staloho rozvytku Ukrainy: dosvid YeS [The problem of energy efficiency in the model of sustainable development of Ukraine: the experience of the EU]. Ekonomika ta upravlinnia natsionalnym hospodarstvom, no. 1 (135), pp. 18-23.

5. Shatylo O. (2013) Svitovyi dosvid zabezpechennia koordynatsii ekonomichnoi ta enerhetychnoi polityky: orhanizatsiinyi aspect [World experience in ensuring coordination of economic and energy policy: organizational aspect]. Derzhavne upravlinnia: udoskonalennia ta rozvytok, vol. 7. Available at: http://www.dy.nayka.com.ua/ ?op $=1 \& z=596$.

6. Enerhetychna bezpeka: yevropeiskyi dosvid [Energy security: European experience]. Financial and Economic Analysis Office in the VRU. Available at: https://feao.org.ua/wp-content/uploads/2016/11/Energy_Security_ Final_27.11.pdf.

7. Polityka energetyczna Polski do 2040 r. [Energy policy of Poland until 2040]. Available at: https://www.gov.pl/ web/klimat/polityka-energetyczna-polski. 